\title{
Taxonomic record and distribution pattern of the banded pond snail, Bellamya bengalensis (Lamarck) (Gastropoda : Mesogastropoda) from pond water habitat of Rajshahi
}

\author{
B. K. Saha*, M. S. Jahan and M. A. Hossain \\ Fisheries Research Laboratory, Department of Zoology, Rajshahi University, Rajshahi-6205, Bangladesh.
}

\begin{abstract}
The study was conducted on the taxonomic record and distribution pattern of the banded pond snail, Bellamya bengalensis (Lamarck ) from the water body of Rajshahi University Campus during the period of January 1995 to December 1996. Eleven generic and 18 species names were recorded including the valid name, Bellamya bengalensis (Lamarck, 1882 ). The shell of B. bengalensis is more or less oval and acuminate with variable and irregular dark bands. The snail was usually found in the littoral zone of the ponds or tanks. This snail was located in the soft or clayey bottom of the pond.
\end{abstract}

Keywords: Taxonomic record; Distribution; Bellamya bengalensis; Rajshahi University Campus; Shell; Littoral zone.

\section{Introduction}

Freshwater gastropods, which constitute the bulk of littoral fauna of tanks, ponds, beels, reservoir and rivers, play an important role in the dynamics of aquatic ecosystems. Sufficient works have been done in abroad on population dynamics, growth, reproduction, life cycle and bioenergetics of a number of gastropods (DeWitt, 1955; Duncan,1959; McCraw,1961; Russel- Hunter, 1961; Eisenberg,1966; Gillespie, 1969; Clampit, 1970; Eckblad,1973; McMohan, 1975; Hunter, 1975 and Browne, 1978 ).

The genus Bellamya is distributed throughout the world except Neotropical region (Preston, 1915 ).

But in Bangladesh, there is a general lack of detailed information on any gastropod species. Only Ali and Chakraborty (1992) and Jahan (1993) mentioned the taxonomic record,distribution and some ecological notes of a few gastropods found in the country. So, this was an attempt to note the taxonomic record and distribution of $B$. bengalensis from Rajshahi water.

\section{Material and methods}

Surveys were made at fortnight intervals throughout the tenure (January1995 to December 1996) based on the observations conducted in selected fish ponds, ditches and irrigated paddy fields of Rajshahi University Campus (Fig.1) to find out the distribution of the pond snail, B. bengalensis.

\section{Results and discussion}

1. Taxonomic record

1.1 Identity Valid name: Bellamya bengalensis (Lamarck, 1822).

1.2 Synonymy

\section{Generic names}

1810 Vivipara, deMontfort, Conch. Syst., ii, p.247.

1851 Viviparus, Dupuy, Hist. nat. des. Moll..........quivivent en France, p.534.

1886 Bellamya, Jousseaume, Bull. Soc. Zool. France, 11: 478.

1915 Paludina, Preston, Faun. Brit. India Moll., p.83.

1928 Bellamya, Prashad, Mem. Indian Mus., 8.

1965 Viviparus, Cockrum \& McCauley, Zoology, p.215.

1967 Viviparus, Hyman, The Invertebrates vi,Mollusca, p. 157.

1968 Viviparus, Morton, Molluscs, Hutchinson University Library, London, p.98.

1972 Viviparus (Paludina), Storer et al., General Zoology, McGraw- Hill Book Company,N.Y., p.505.

1974 Viviparus, Barnes, Invertebrate Zoology, p.336.

1989 Bellamya, Subba Rao, Handbook: Freshw. Moll. India, p.44. 


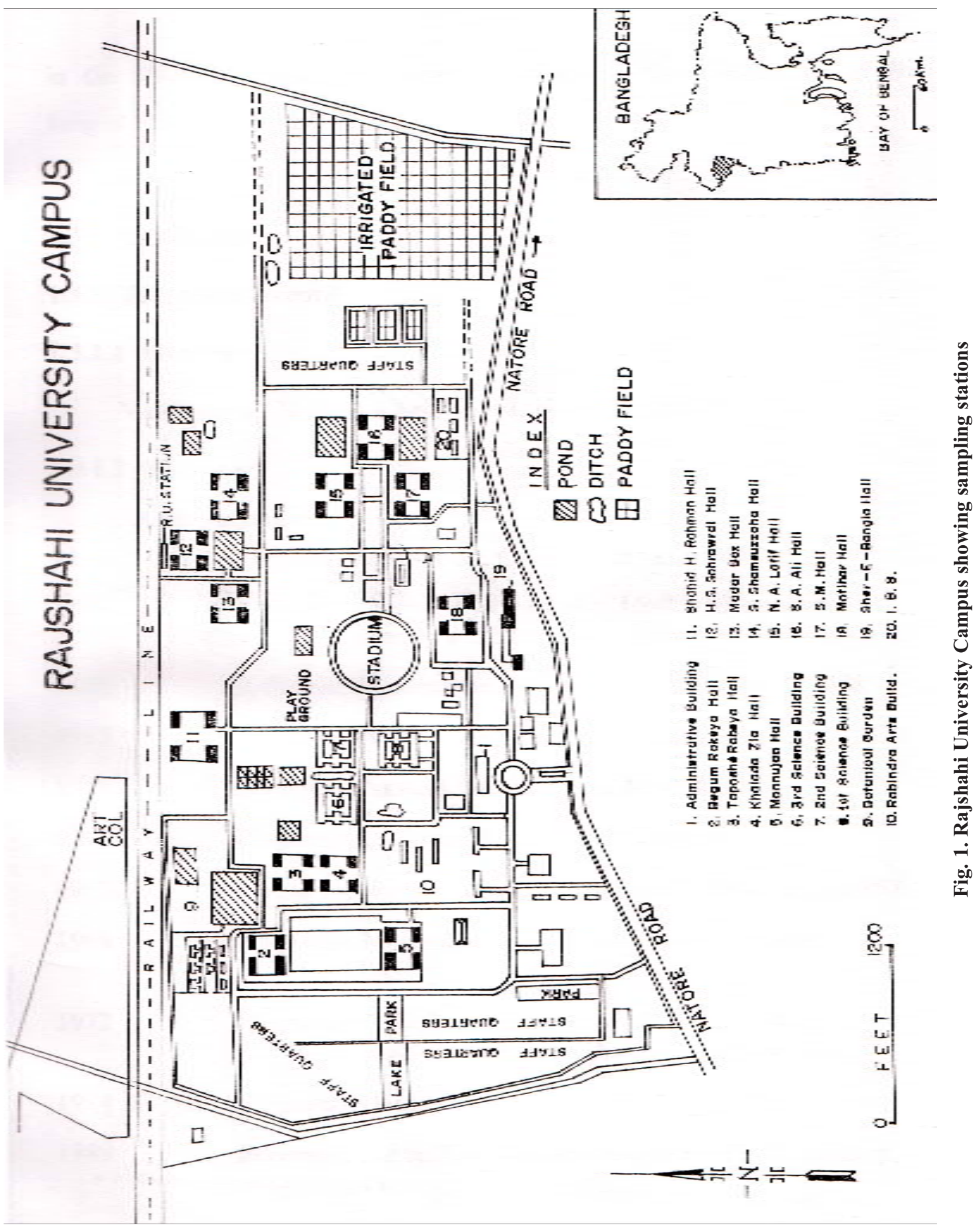


Species name

1882 P. bengalensis, Lamarck, Hist. nat. Anim. Sans. Vert., 6(2) :174.

1882 B. bengalensis, Lamarck, in Handbook : Freshw. Moll. India, Subba Rao, p. 45.

1915 V. bengalensis, Preston, Faun. Brit. India Moll., p.83.

1920 V. bengalensis, Annandale, Rec. Indian Mus.xix, p.113.

1921 V.bengalensis, Annandale \& Sewell, Rec.Indian Mus.,22:267, pl.1, figs.1-3.

1928 B. bengalensis, Prashad, in Handbook : Freshw. Moll. India, Subba Rao, p.45.

1928 B. bengalensis, Prashad, Mem. Indian Mus., 8.

1928 V. bengalensis, Prashad, Mem.Indian Mus.,8,p.190.

1929 V. bengalensis, Srivastava Rao, Rec. Indian Mus. xxxi,p. 274.

1958 V. bengalensis, Ramamoorthi, J. zool. Soc. India, 10(11), p.35.

1968 V. bengalensis, Biswas \& Ghose, J. Zool. Lond., 156: p. 325.

1977 V. bengalensis, Sengupta, Acta. Zool., 58(3), , p.123.

1980 V. bengalensis, Raut, Bull. zool.Surv. India, Calcutta, 3(1\&2).

1981 V. bengalensis, Raut, Proc. Symp. Ecol. Anim. Popul. Zool. Surv. India, pt.2, p.163.

1981 V. bengalensis, Raut, Bull. zool. Surv. India, 4(1), p.13.

1986 B. bengalensis, Raut \& Bhattacharya, Environ. Ecol., 4, No. 2.

1989 B. bengalensis, Subba Rao, Handbook : Freshw. Moll. India, p.45.

1996 B. bengalensis, Jahan \& Zaman, 4th Int.Cong. Med. Appl. Malac..

The name of $B$. bengalensis has been used by different authors such as Subba Rao and Mitra (1980), Khan \& Chaudhuri (1984), Raut (1986), Subba Rao (1989) and Jahan (1993).

\section{Systematic position}

$\begin{array}{ll}\text { Kingdom } & \text { Animalia } \\ \text { Phylum } & \text { Mollusca } \\ \text { Subphylum } & \text { Conchifera } \\ \text { Class } & \text { Gastropoda } \\ \text { Subclass } & \text { Prosobranchia } \\ \text { Order } & \text { Mesogastropoda }\end{array}$

Family

Subfamily

Genus

Species

\section{Diagnostic characters}

The shell of $B$. bengalensis is more or less oval in shape and acuminate. The upper part of the shell is slightly conoidal rather than conical. The body whorl is evenly convex in profile. The aperture is sub-circular and has a narrow black margin. It is slightly oblique. The umbilicus is narrow. The colouration varies considerably but it is never brilliant. The ground colour is greenish and opaque. The dark bands are variable and irregular. The operculum is moderately thin and of a deep brownish complexion. The external surface is convex, the outer margin strongly curved, the inner margin slightly sinuate and the posterior extremity bluntly pointed. This snail gives birth to a large number ( 001-114) of fully developed youngs ( Fig. 2).

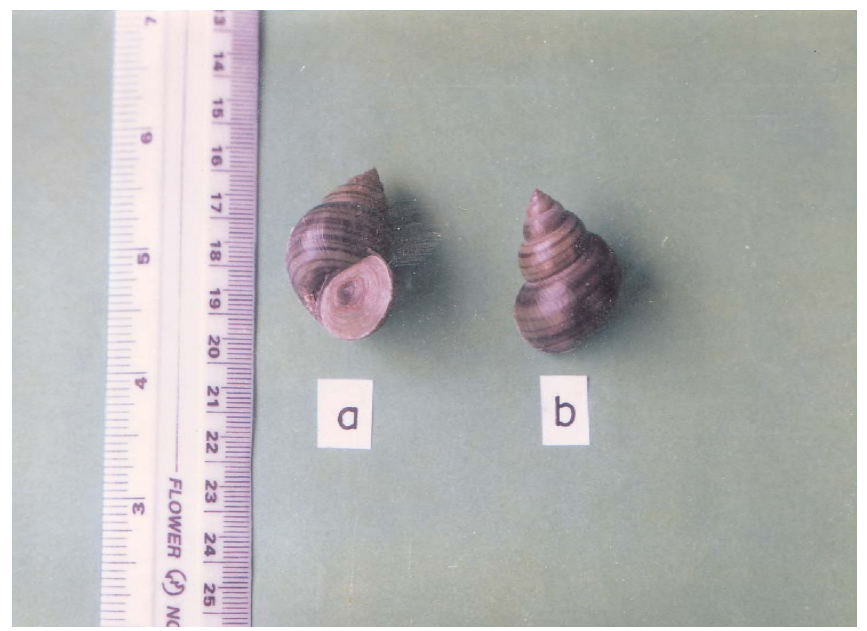

Fig. 2. Apertural (a) and abapertural (b) views of $B$. bengalensis

\section{Distribution}

Bellamya bengalensis generally occurs in permanent stagnant waterbodies such as ponds, tanks, beels etc. in Bangladesh.This snail is normally found in the littoral zone of the ponds or tanks situated in Rajshahi University Campus. In the monsoon, this snail was dispersed in the irrigated paddy fields and ditches in large numbers. The soft or clayey bottom contained this snail while sandy bottom generally contained no such snail. During the dry season 
(December to June ), only the empty shells were observed in the irrigated paddy fields, ditches and canals. The present observation also supports the description of Subba Rao (1989) that the young ones of B. bengalensis keep themselves attached to the floating sticks and weeds but adults are usually confined to the muddy bottom of ponds, ditches and other habitats.

\section{References}

Ali S and Chakraborty T (1992), Bangladesh Mitha Panir Amerudandi Prani (A book on Freshwater Invertebrates of Bangladesh). Bangla Academy, Dhaka, Bangladesh, Ist edition, pp. 208.

Browne AR (1978), Growth, mortality, fecundity, biomass and productivity of lake populations of the prosobranch snail, Viviparus georgianus. Ecology, 59: 742756.

Clampit PT (1970), Comparative ecology of the snails, Physa gyrina and Physa integra (Basommatophora: Physidae ).Malacologia, 10 : 113-151.

DeWitt RM (1955), The ecology and life history of the pond snail, Physa gyrina. Ecology, 36 : 40-44.

Duncan CJ (1959), The life cycle and ecology of a freshwater snail, Physa fontinalis. J. Anim.Ecol., 28 : 97-117.

Eckblad JW (1973), Population studies of three aquatic gastropods in an intermittent brackishwater. Hydrobio logia, 41 : 199-219.

Eisenberg RM (1996), The regulation of density in a natural population of the pon snail, Lymnaea elodes. Ecology, 47: 889-906.

Gillespie DM (1969), Population studies of four species of molluscs in the Madison river.Yellowstone National Park. Limnol. Oceanogr., 14 : 101-114.

Hunter RD (1975), Growth, fecundity and bioenergetics in three populations of Lymnaea palustris in upstate New York. Ecology, 56 : 50-63.
Jahan MS (1993), Some terrestrial and freshwater gastropods of Bangldesh with their ecological notes. Univ. j. zool. Rajshahi Univ., 12: 65-71.

Khan RA and Chaudhuri S (1984), The population and production ecology of a freshwater snail, Bellamya bengalensis (Lamarck) (Gastropoda : Viviparidae) in an artificial lake of calcutta, India. Bull. Zool. Surv. India, 5 (2\& 3): 59-76.

McCraw BM (1961), Life history and growth of the snail, Lymnaea humilis. Trans. Am. micros Soc., 80: 16-27.

McMahon RF (1975), Bioenergetics variation in three natural populations of the freshwater limpet, Levapex fuscus. Proc. malac. Soc. Lond., 42: 331-351.

Preston HB (1915), The fauna of British India including Ceylon and Burma : Mollusca ( Freshwater Gastropoda and Pelecypoda). Taylor and Francis, Lond., pp.1-244.

Raut SK (1986), Snails and slugs in relation to human diseases. Environ. Ecol. 4: 130-138.

Russel-Hunter WD (1961), Annual variations in growth and density in natural populations of freshwater snails in the west of Scotland. Proc.zool. Soc. Lond.,136: 219253.

Subba Rao NV and Mitra SC (1980), Systematics and ecology of freshwater gastropods of parasitological importance. Snails, flukes and man, edited by M.S.Jairajpuri. Zool. Surv. India, Calcutta, pp. 47-63.

Subba Rao NV (1989), Handbook of Freshwater Molluscs of India, edited by the Director. Zool. Surv. India, Calcutta, pp.289.

Received: 15 September 2011; Revised: 15 May 2012; Accepted: 20 May 2012. 